\title{
Growth Performance of Microalgae Exposed to $\mathrm{CO}_{2}$
}

\author{
Alessandro Minillo, Hania Cardamoni Godoy, and Gustavo Graciano Fonseca
}

\begin{abstract}
The increase of $\mathrm{CO}_{2}$ emission and other gases of greenhouse effect have caused global debates concerning climatic alterations, stimulating the development of mitigative strategies. Researches in this area include $\mathrm{CO}_{2}$ kidnapping through aquatic microalgae production, as well as their use in the production of biofuels. The aim of this work was to determine the growth kinetics of microalgae (Chlorella sp, Scenedesmus spinosus, Scenedesmus acuminatus and Coelastrum sp.) exposed directly to $\mathrm{CO}_{2}$. Measurements of microalgae growth and $\mathrm{pH}$ from medium were taken weekly. The results showed that carbon dioxide promoted growth inhibition in most microalgae. This condition should be considered for the developing of operational strategies and in projects of photobioreactors for the biological conversion of $\mathrm{CO}_{2}$.
\end{abstract}

Index Terms-Microalgae, carbon capture, biofuel, kinetic.

\section{INTRODUCTION}

With the global population growth and industrialization increase, energy consumption has consequently shown an expressive rise in recent decades. In this scenario, about $85 \%$ of global energy demand is supported by the burning of fossil fuels [1].

Due to the uncontrolled consumption of fossil fuels as the primary source, it becomes necessary the search for new renewable and clean energy matrices to amortize the effects of economic dependence of natural resources. However, it is evident that the requirements for fossil fuels, mainly for power generation and industrial production, will be still necessary in the future. Burning these fossil fuels releases large amounts of $\mathrm{CO}_{2}$ into the atmosphere, which affects the balance in the presence of these gases, leading directly to the greenhouse effect. Although $\mathrm{CO}_{2}$ emissions through anthropogenic activities are relatively low if compared with the natural flows of carbon, e.g. the photosynthesis flow, the greater release is due by the influences of the global climate in a very short period of time [2]. $\mathrm{CO}_{2}$ levels in the atmosphere have increased from 260 to $380 \mathrm{ppm}$ in the past 100 years [3].

The increased concentration of $\mathrm{CO}_{2}$ in the atmosphere influences the balance of input and output energy on its system, leading to an increase in the average temperature of the earth's surface, known as global warming, which is currently a major environmental problem [4] Thus, $\mathrm{CO}_{2}$ has often been cited as the main greenhouse gas (GHG), as well as the cause of climate change. Although there are

Manuscript received October 25, 2012; revised January 14, 2013. This work was supported by the Brazilian National Counsel of Technological and Scientific Development (CNPq).

A. Minillo and H. C. Godoy are with the State University of Mato Grosso do Sul, Dourados, MS 79.804-970 Brazil.

G. G. Fonseca is with the Federal University of Grande Dourados, Dourados, MS 79.804-970 Brazil (e-mail: ggf@ufgd.edu.br). uncertainties on this subject, in recent years have been published many studies on the need to reduce $\mathrm{CO}_{2}$ emissions so as not to promote climate change [5].

Several alternatives have been studied in order to promote the reduction of emissions, sequestration and biological fixation of carbon dioxide emitted by stationary sources. One of them is the use of reforestation of photosynthetic organism with the capacity to absorb carbon dioxide from the atmosphere [4], but currently the alternative that has been more studied is the cultivation of microalgae. Microalgae are the main responsible for the biological uptake of atmospheric $\mathrm{CO}_{2}$ in the oceans that cover $3 / 4$ of the globe surface, once that they are present in large numbers in the water column [6]. A portion of the $\mathrm{CO}_{2}$ absorbed by microalgae is transferred to the deep ocean in a process known as "biological pump" [7]. This process, along with direct diffusion of $\mathrm{CO}_{2}$ into the water, prevents that the buildup of "greenhouse effect" gases became even greater.

Besides having the capacity to fix carbon dioxide from air, using it as a carbon source, microalgae have the capacity of cycling the organic matter and may offer during its growth a number of mineral elements, vitamins, lipids, pigments and proteins, presenting thus large industrial and commercial applicability [8].

Microalgae can be utilized to produce hydrogen from methane by anaerobic digestion of biomass and biodiesel from intracellular lipid content [9]. According to Teixeira and Morales [10], the microalgae oils possess physical and chemical characteristics similar to that found in the vegetable oils and therefore can be considered as potential raw material for biodiesel production.

In the production of biodiesel, microalgae have several advantages when compared to plants. Microalgae grow at higher rates, have greater oil yield and productivity and can be cultivated on land unsuitable for agriculture. In addition, they are able to remediate wastewater by consuming its nitrogen and phosphorus [8] or even heavy metals [10]. Moreover, they can grow in brackish and/or salted water [4] and have a wide tolerance to environmental extremes, being able to growth in intensively cultivated small spaces [11] using much less water for its cultivation when compared to the culture of plants [12], and also has high efficiency of carbon dioxide fixation [13].

This way, considering the crescent demand for new alternatives that enable the provision of more green energy sources, a strong enthusiasm has been generated around the great potential offered by microalgae either in the production of biomass or biofuels, which represents a promising proposal of reducing the dependence for fossil fuels, without compromising the environment.

The aim of this work was to evaluate the growth performance of four different isolated microalgae strains of 
the species Chlorella sp., Scenedesmus spinosus, Scenedesmus acuminatus and Coelastrum sp. grew in medium containing $\mathrm{CO}_{2}$ as the sole carbon source.

\section{MATERIALS AND MethodS}

\section{A. Microalgae Collection, Isolation and Identification}

Microalgae used in this study were collected using a phytoplankton net (20 $\mu \mathrm{m}$ mesh opening), in a mesocosmos located in the university campus. After collection they were taken to the laboratory for isolation and culture.

For the microalgae isolation were utilized excavated blades with the aid of a stereoscope microscope, where the cells were isolated one by one by using glass capillary needles, being subsequently inserted and maintained in test tubes $(5 \mathrm{ml})$ containing synthetic cultivation medium (Chu-12). After isolation, consecutive samplings of the biological material were carried out until achieve the complete purification of microalgae.

In parallel, the identification of the isolated microalgae was performed in test tubes using appropriate laminas and laminules with the assistance of a binocular optical microscope, according to morphological and morphometric characteristics for analysis achieved at the lowest possible taxonomic level based on literature [14]. These cultures were kept in BOD incubator in synthetic medium (Chu-12) at 25 ${ }^{\circ} \mathrm{C}$, 1 klux light, $12 \mathrm{~h}$ photoperiod and constant stirring.

\section{B. Microalgae Growth Experiments}

Growth experiments were carried out in $500 \mathrm{ml}$ Erlenmeyer flasks, sealed, fed with $400 \mathrm{ml}$ synthetic medium (Chu-12). Cultivations started with the addition of $2.5 \mathrm{ml}$ of microalgae inoculum (density of approximately $8-25 \times 10^{4}$ cells / ml). Each treatment was represented by a single species, which was cultivated in triplicate. The tests were operated in a BOD incubator at $25{ }^{\circ} \mathrm{C}$, light intensity of 10 klux, $12 \mathrm{~h}$ light photoperiods, with carbon dioxide provided under direct injection from a pressured cylinder. The control treatment was performed at the same conditions described above, except by the aeration, maintained by aquarium pumps.

Samplings were carried out at intervals of 4 days. Algae growth and $\mathrm{pH}$ were monitored. For the cell count was used a Neubauer chamber. All assays were accomplished after verified the stationary growth phase of the microalgae cultures.

\section{Analysis of Results}

All results were analyzed with a software "Statistica for Windows" version 5.1. Regression analysis $\left(\mathrm{r}^{2}\right)$ and the Spearman correlation test $(\mathrm{R})$ we performed, where significance was considered for $p \geq 0.05$. Figures were elaborated with the software Origin 8.0. Parameters considered for the results' analysis were microalgae growth and $\mathrm{pH}$.

\section{RESULTS AND DISCUSSION}

After isolation, it was obtained different species of microalgae, being selected four species (Chlorella sp,
Scenedesmus spinosus, Scenedesmus acuminatus and Coelastrum $\mathrm{sp}$ ) due its high potential described in literature for producing oils. Growth kinectis of these four microalgae species in treatments with and without $\mathrm{CO}_{2}$ are presented in Fig. 1 and Fig. 2, respectively.

According to Fig. 1, there was distinction in the growth rates between the species in the presence of $\mathrm{CO}_{2}$. The species that obtained best growth performance was $S$. spinosus, followed by $S$. acuminatus, Chlorella sp. and Coelastrum sp. In this experiment it can be seen that the treatments with Chlorella sp. and Coelastrum sp. reached its maximums in the $16^{\text {th }}$ day, while the $S$. spinosus growth apex was found on the $24^{\text {th }}$ day and for $S$. acuminatus on the $28^{\text {th }}$ day. S. spinosus showed higher density among all species analyzed when directly exposed to $\mathrm{CO}_{2}$ injection.

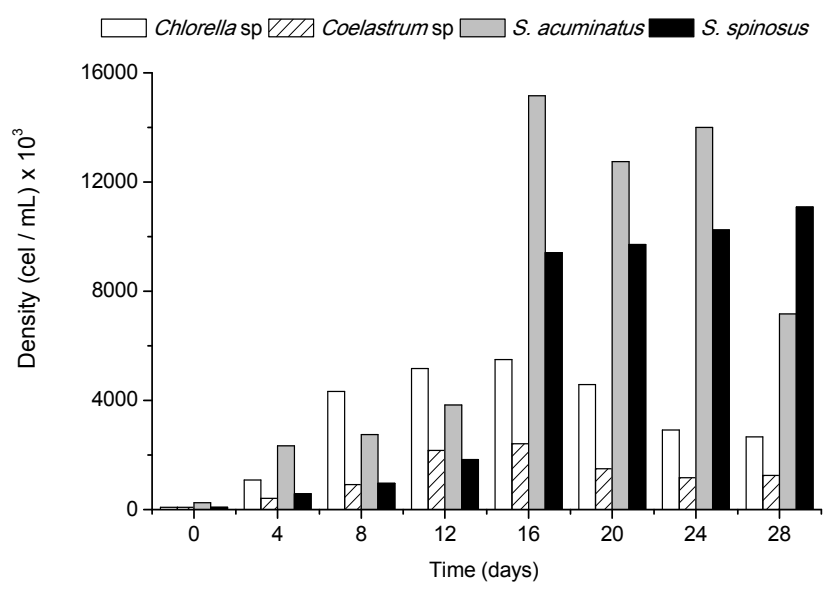

Fig. 1. Growth kinetics of four microalgae species in treatments with $\mathrm{CO}_{2}$.

When air was injected without $\mathrm{CO}_{2}$ supplementation, there was a change in the profile among the favored species. Growth was higher for $S$. acuminatus. Chlorella sp., $S$. spinosus and Coelastrum sp. followed respectively in growth. In this assay, Coelastrum sp and $S$. spinosus showed their highest densities on the $16^{\text {th }}$ day, while Chlorella sp. recorded its maximum growth on the $20^{\text {th }}$ day and $S$. acuminatus on the $28^{\text {th }}$ day. $S$. acuminatus was the species that had the highest number of reproduced cells (Fig. 2).

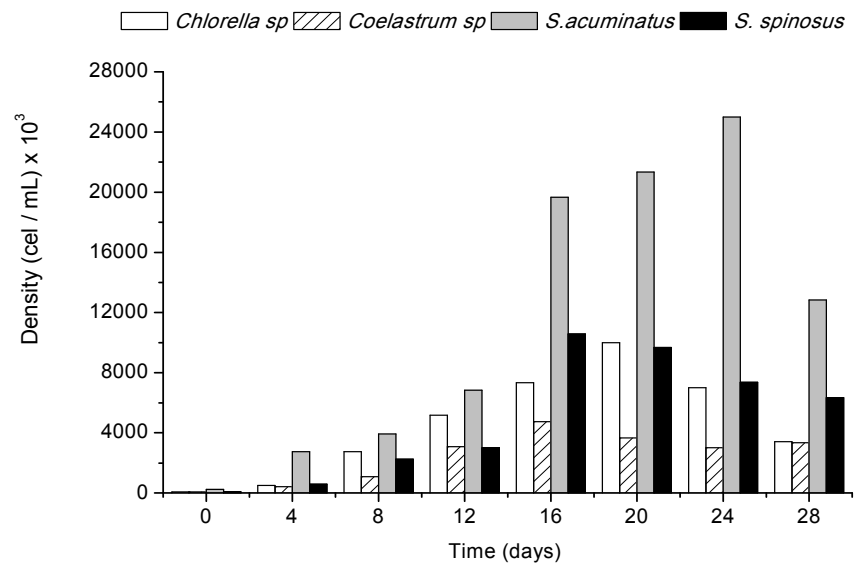

Fig. 2. Growth kinetics of four microalgae species in treatments without $\mathrm{CO}_{2}$.

According to Table I, it was demonstrated by the regression analysis that almost all treatments $(p \geq 0.05)$ were significant, except for Chlorella sp. when maintained in the presence of $\mathrm{CO}_{2}$. However, the highest correlation with the 
density and $\mathrm{pH}$ was obtained with Chlorella sp. with $\mathrm{O}_{2}$ (without $\mathrm{CO}_{2}$ ) and $\mathrm{S}$. spinosus with $\mathrm{CO}_{2}$. Regarding the Spearman correlation test, the only significant results were obtained with Chlorella sp. with $\mathrm{O}_{2}$ (without $\mathrm{CO}_{2}$ ) and $S$. spinosus with $\mathrm{CO}_{2}$.

TABLE I: REPRESENTATION BY SPECIES OF THE REGRESSION ANALYSIS $\left(\mathrm{R}^{2}\right)$ AND THE SPEARMAN CORRELATION TEST (R).

\begin{tabular}{lcccc}
\hline \hline Species & $\mathrm{R}\left(\mathrm{CO}_{2}\right)$ & $\mathrm{R}\left(\mathrm{O}_{2}\right)$ & $\mathrm{r}^{2}\left(\mathrm{CO}_{2}\right)$ & $\mathrm{r}^{2}\left(\mathrm{O}_{2}\right)$ \\
\hline Chlorella sp. & 0.12 & $0.81^{*}$ & 0.016 & $0.54^{*}$ \\
Coelastrum $\mathrm{sp}$. & $0.45^{*}$ & $0.45^{*}$ & 0.21 & 0.15 \\
S. spinosus & $0.81^{*}$ & $0.74^{*}$ & $0.59^{*}$ & 0.28 \\
S. acuminatus & $0.54^{*}$ & $0.74^{*}$ & 0.19 & 0.26 \\
\hline \hline
\end{tabular}

(*) VALUES CONSIDERED SIGNIFICANT BETWEEN DENSITY AND PH FOR SPECIES, CONSIDERING $\mathrm{P} \geq 0.05$.

Growth curves and the relationship between the development of microalgae in relation to $\mathrm{pH}$ of the medium in treatments with or without $\mathrm{CO}_{2}$ are presented for Chlorella sp. (Fig. 3), Coelastrum sp. (Fig. 4), S. spinosus (Fig. 5) and $S$. acuminatus (Fig. 6).
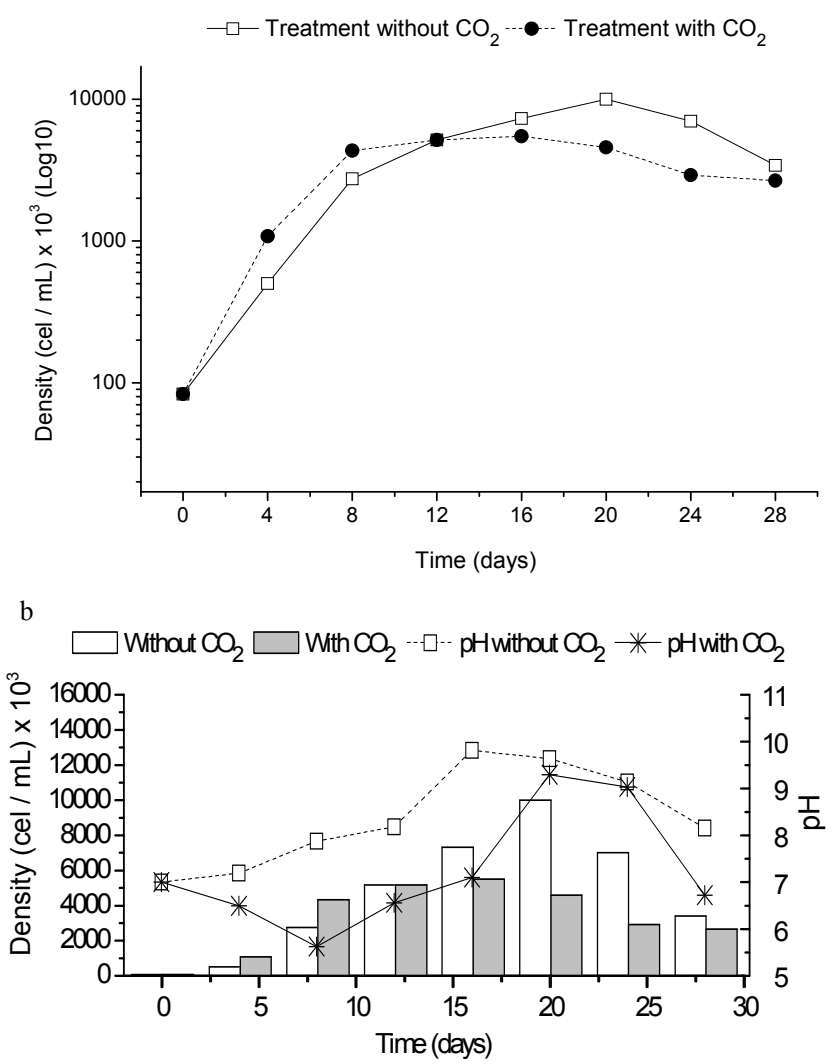

Fig. 3. Chlorella sp.: (a) growth curve and (b) relationship between the development of microalgae in relation to $\mathrm{pH}$ of the medium in treatments with or without $\mathrm{CO}_{2}$

According to Fig 3a, initially Chlorella sp. developed more rapidly in the treatment with $\mathrm{CO}_{2}$, reaching the log phase in 8 days, while its stationary phase started from the $12^{\text {th }}$ day. The same species when maintained in $\mathrm{O}_{2}$ began its development more slowly, attaining the log phase on the $14^{\text {th }}$ day, with its stationary phase beginning after the $20^{\text {th }}$ day. It was still observed that on the $12^{\text {th }}$ day, the microalgae Chlorella sp. contained the same density in the medium for both treatments whereas from this period there was an inversion in the cells growth rate.
With respect to $\mathrm{pH}$, Chlorella sp. in medium without $\mathrm{CO}_{2}$ had developed with higher $\mathrm{pH}$. With $\mathrm{CO}_{2}$ there was no correlation between these two variables (Fig. 3b).

The microalgae Coelastrum $\mathrm{sp}$. produced the same number of cells in both treatments until the $8^{\text {th }}$ day. From the $12^{\text {th }}$ day, this species reproduced more actively in medium with $\mathrm{O}_{2}$, where the log phase was achieved both at $16^{\text {th }}$ day and its stationary phase has initiated from the $24^{\text {th }}$ day (Fig. 4a). In both treatments the growth curve had the same behavior, but cell production was higher in treatments maintained with $\mathrm{O}_{2}$.

Regarding the $\mathrm{pH}$, Coelastrum sp. presented biomass increase for both treatments with and without $\mathrm{CO}_{2}$. There was a relation between the biomass and $\mathrm{pH}$, being that after the $4^{\text {th }}$ day there was a fall, then a peak, followed by a slight reduction in their values on the $20^{\text {th }}$ day (Fig. 4b).

From Fig. 5a, it was observed that $S$. spinosus presented a growth behavior very similar for both treatments. Which has differed was that in medium without $\mathrm{CO}_{2}$ was reproduced more cells than in medium with $\mathrm{CO}_{2}$, but the log phase began on $4^{\text {th }}$ day. S. spinosus also had its maximum production at the $16^{\text {th }}$ day for both treatments, but it had better reproduced in the absence of $\mathrm{CO}_{2}$. Depending on the $\mathrm{pH}$, there was a decrease in $\mathrm{pH}$ on the $4^{\text {th }}$, increasing their growth until the $24^{\text {th }}$ day, where there was a fall again (Fig. 5b).
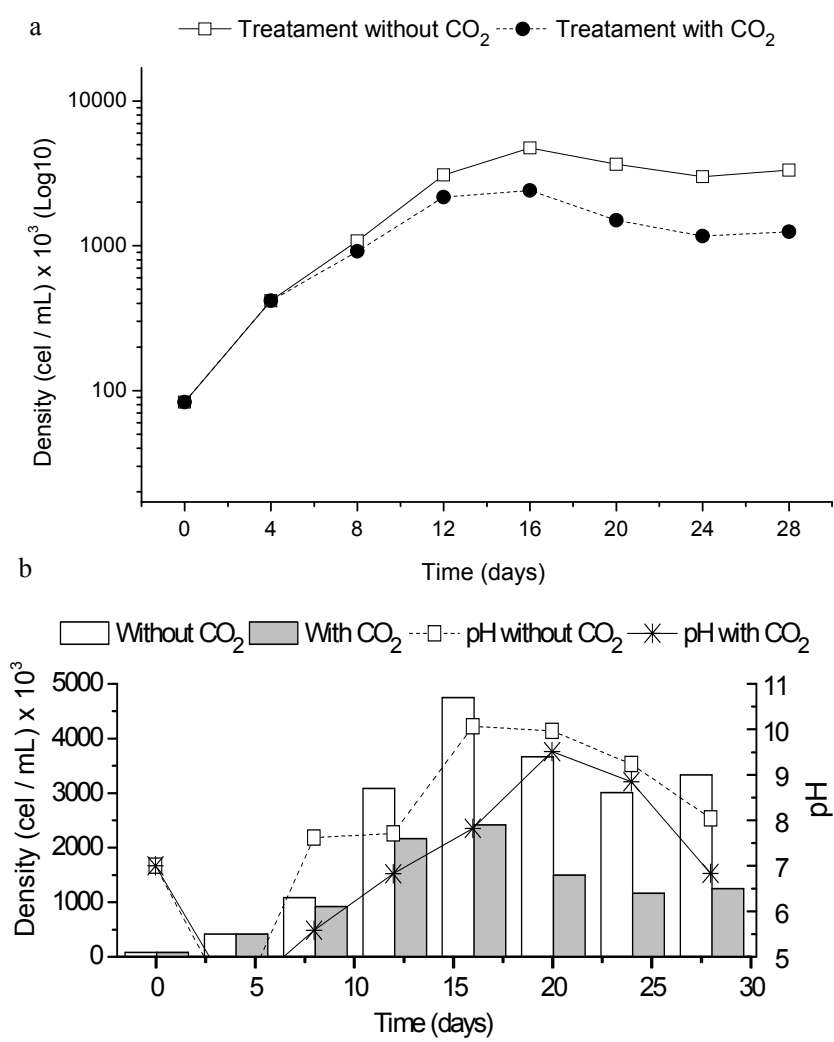

Fig. 4. Coelastrum sp.: (a) growth curve and (b) relationship between the development of microalgae in relation to $\mathrm{pH}$ of the medium in treatments with or without $\mathrm{CO}_{2}$

Analyzing the growth of $S$. acuminatus, it observes that this species showed higher values for treatments with only natural air without $\mathrm{CO}_{2}$ supplementation, represented at $28^{\text {th }}$ day (Fig. 6a), where the pH was approximately 7.0 (Fig. 6b). This microalga also presented similar growth profile for both treatments, showing a slight decline in growth in medium with $\mathrm{CO}_{2}$ between $4^{\text {th }}$ and $12^{\text {th }}$ days. From the $12^{\text {th }}$ day there 
was a quick lag phase where at the $16^{\text {th }}$ day the number of cells produced in medium with $\mathrm{CO}_{2}$ reached approximately the same number as that produced in medium without $\mathrm{CO}_{2}$. Moreover, from the same $16^{\text {th }}$ day, there was a slight decrease in medium without $\mathrm{CO}_{2}$, reaching the stationary phase even before that the $S$. acuminatus produced with $\mathrm{CO}_{2}$.

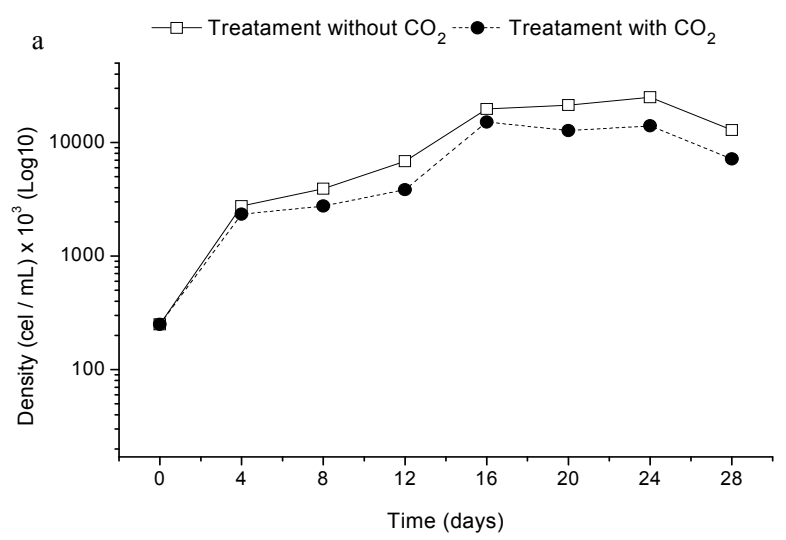

b

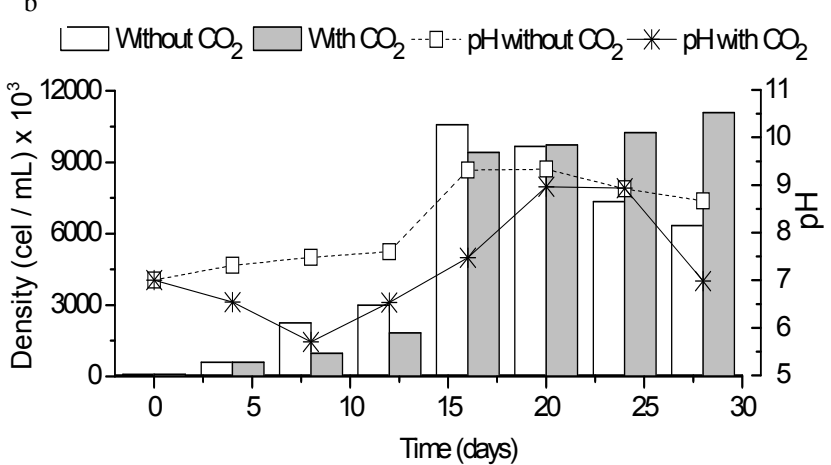

Fig. 5. S. spinosus: (a) growth curve and (b) relationship between the development of microalgae in relation to $\mathrm{pH}$ of the medium in treatments with or without $\mathrm{CO}_{2}$

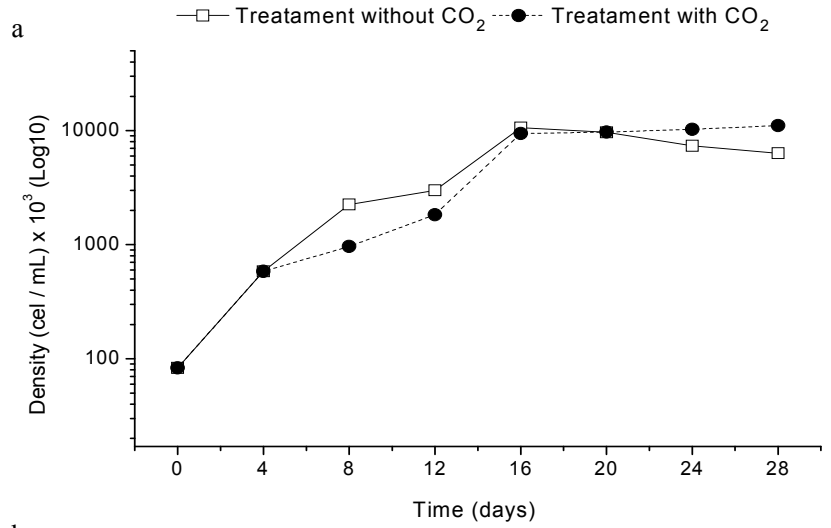

$\mathrm{b}$ $\checkmark$ Without $\mathrm{CO}_{2} \square$ With $\mathrm{CO}_{2} \cdots-\cdots$ pH without $\mathrm{CO}_{2} * \mathrm{pH}^{-\cdots}$ with $\mathrm{CO}_{2}$

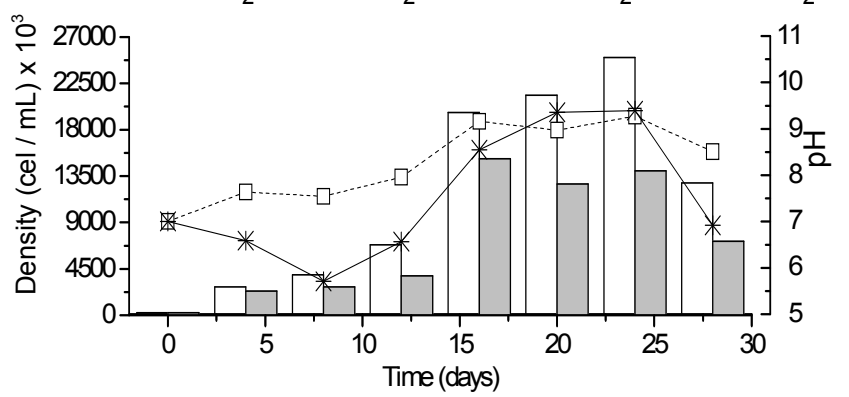

Fig. 6. S. acuminatus: (a) growth curve and (b) relationship between the development of microalgae in relation to $\mathrm{pH}$ of the medium in treatments with or without $\mathrm{CO}_{2}$
It is evident, if we analyze the growth performance of Chlorella sp., Coelastrum sp. and S. spinosus with and without $\mathrm{CO}_{2}$, that all grew better in absence of $\mathrm{CO}_{2}$ supplementation. This may have occurred because these species are sensitive to the presence of $\mathrm{CO}_{2}$ because the gas in contact with the medium promotes greater concentration of carbonic acid $\left(\mathrm{H}_{2} \mathrm{CO}_{3}\right)$ [15], promoting acidification of the medium. Possibly these three microalgae species showed lower tolerance limits under acidic environment to survive, therefore grew better in medium maintained with natural air, where the $\mathrm{pH}$ of medium is more alkaline.

The microalga $S$. acuminatus when compared individually to the other species, presented a better growth performance, based on the higher growth rate observed in medium without $\mathrm{CO}_{2}$ supplementation, but if compared with other microalgae species analyzed here, it was observed that for treatments, i.e. with or without $\mathrm{CO}_{2}$ supplementation, the maximum number of cells attained was always superior.

Probably the nutrient available in the medium without $\mathrm{CO}_{2}$ became scarce than in the medium with $\mathrm{CO}_{2}$, due to its high growth rate. However, if compared to the larger amount of cells reproduced, it has that the $S$. spinosus obtained the larger number than $S$. acuminatus, even that the first had presented better development in the presence of $\mathrm{O}_{2}$. A plausible explanation for it is the fact that the reproduction rate of these cells is slower for $S$. spinosus than for $S$. acuminatus, which was observed at the time that the analyses were performed.

\section{CONCLUSION}

Among the four microalgae species studied, S. acuminatus was the one that presented better performance in the growth of cells for both treatments tested, especially in medium with aeration without $\mathrm{CO}_{2}$ supplementation. S. spinosus, although having obtained a smaller number of cells produced, deserves attention due their better developed on medium with $\mathrm{CO}_{2}$.

The results indicated that the four isolated microalgae strains showed different profiles in their growth when exposed to $\mathrm{CO}_{2}$, which is directly linked to the adaptive mechanisms that each species has for better absorption of atmospheric $\mathrm{CO}_{2}$. These microorganisms present great potential for future studies related to the development of the clean mechanism, which may assist in the remediation of the problems associated with the greenhouse gases.

\section{REFERENCES}

[1] S. A Rackley, Carbon Capture and Storage, Elsevier. 2010.

[2] R. E. Hester and R. M. Harrison, Carbon Capture: Sequestration and Storage, RSC Pub. 2010.

[3] U. Siegenthaler, T. F. Stocker, E. Monnin, D. Lüthi, J. Schwander, B. Stauffer, D. Raynaud, J. M. Barnola, H. Fischer, V. M. Delmontt, and J. Jouzel, "Stable carbon cycle-climate relationship during the late Pleistocene," Science, vol. 310, pp. 1313, 2005.

[4] L. Borges, B. M. De Faria, C. Odebrecht, and P. C. Abreu, "Potencial de absorção de carbono por espécies de microalgas usadas na aquicultura: primeiros passos para o desenvolvimento de um Mecanismo de desenvolvimento Limpo," Atlântica, Rio Grande, vol. 29, pp. 35-46, 2007.

[5] N. Adger et al., Climate change 2007: climate change impacts, adaptation and vulnerability: fourth assessment report. [Online]. Available: http://www.ipcc.ch. 2007. 
[6] P. G. Falkowski and J. A. Raven, Aquatic Photosynthesis. Oxford. Blackwell Scientific Publishers. pp. 374, 1997.

[7] C. Lalli and T. Parsons, Biological Oceanography: an Introduction. Oxford, Butterworth \& Heinemann Ltd. pp. 301, 1993.

[8] S. A. Khan, Rashmi, M. Z. Hussain, and S. Prasad, U. C. Banerjee, "Prospects of biodiesel production from microalgae in India," Renewable and Sustainable Energy Reviews, vol. 13, pp. 2361-2372, 2009.

[9] Y. Chisti, "Biodiesel from microalgae," Biotechnology Advances, vol. 25, pp. 294-306, 2007.

[10] C. M. L. L. Teixeira and E. Morales, "Microalga como matéria-prima para a produção de biodiesel," Annals of I Congress of the Brazilian Network of Biodiesel Technology, Brasília, 2006.

[11] N. Kurano, H. Ikemoto, H. Miyashita, T. Hasegawa, H. Hata and S. Miyach, "Fixation and utilization of carbon dioxide by microalgal photosynthesis," Energy Convers. Mgmt. vol. 36, pp. 6-9, 689-692, 1995.

[12] J. Sheehan, T. Dunahay, J. Benemann, and P. Roessler, $A$ look back the U.S. Departament of Energy's Aquatic Species Program-Biodisel from Algae, Colorado. 1998

[13] P. H. Raven, R. F. Evert, and H. Curtis, Vegetal Biology; ed. Guanabara Dois, $2^{\mathrm{a}}$ ed., 1978

[14] C. E. M. Bicudo and M. Menezes, Gêneros de algas continentais do Brasil (Chave para identificação e descrições). RiMa, São Carlos. 2006.
[15] V. Bashkin and M. Radojevic, "Acid rain and its mitigation in Asia," International Journal of Environmental Studies, vol. 60, pp. 205-214, 2003.

Alessandro Minillo is currently a visiting researcher of PETROBRAS SA at the State University of Mato Grosso do Sul, Brazil. He has obtained BSc (Oceanology) and M.Sc. (Physical, Chemical and Geological Oceanography) from the Federal University of Rio Grande and PhD (Sciences of Environmental Engineering) from the Federal University of São Carlos, Brazil. He recently concluded his activities as Visiting Specialist in the Bioengineering Group, in the Faculty of Engineering of the Federal University of Grande Dourados, Brazil.

Hania Cardamoni Godoy recevied BSc in Biological Sciences by the Federal University of Grande Dourados and now is doing her MSc. in Natural Resources by the State University of Dourados, Brazil.

Gustavo Graciano Fonseca is adjunct professor and leader of the Bioengineering Group in the Faculty of Engineering of the Federal University of Grande Dourados, Brazil. He has obtained BSc and M.Sc. in Food Engineering from the Federal University of Rio Grande and Federal University of Santa Catarina, respectively, and $\mathrm{PhD}$ in Biotechnology from the University of São Paulo, Brazil. 